\title{
Monitoring of essential and toxic metals in imported herbal teas marketed in selected cities in Southern Nigeria: A health risk assessment study
}

$$
\text { *11PATRICK-IWUANYANWU, KC; }{ }^{2} \text { UDOWELLE, NA }
$$

\author{
${ }^{I}$ Department of Biochemistry (Toxicology Unit), Faculty of Science, University of Port-Harcourt, Nigeria \\ ${ }^{2}$ Department of Experimental Pharmacology and Toxicology, Faculty of Pharmaceutical Sciences, University of Port-Harcourt, Nigeria \\ Corresponding Author e-mail:kctrendy@yahoo.co.uk
}

\begin{abstract}
Teas are the most consumed beverage worldwide after water, and its consumption among Nigerians has increased over the past decades due to its documented health potentials. The objective of this study was to investigate the levels of heavy metals $(\mathrm{Pb}, \mathrm{Ni}, \mathrm{Cr}, \mathrm{Zn}, \mathrm{Fe}$ and $\mathrm{Cu})$ in herbal teas and also to estimate human health risk associated with their consumption. Twenty eight samples of commonly consumed herbal tea bags were purchased from major supermarkets in Port-Harcourt, Yenagoa and Owerri in Southern Nigeria. They were digested, ashed and analysed using atomic absorption spectroscopy (AAS). Heavy metal concentration varied among the different brands of herbal teas in the study whereas the concentrations of $\mathrm{Cd}, \mathrm{Cr}$ and $\mathrm{Ni}$ in some herbal teas were higher than the permissible limit in China. The estimated daily intake (EDI) of heavy metals via consumption of herbal teas showed that Fe contributed the most to the daily intake of metals while $\mathrm{Pb}$ contributed the least. The mean average of EDI of heavy metals were $0.657,0.118,0.014,0.014,0.008$ and $0.0009 \mathrm{mg} / \mathrm{kg} / \mathrm{day} \mathrm{Bw}$ in the order of $\mathrm{Fe}>\mathrm{Zn}>\mathrm{Cu}>\mathrm{Cr}>\mathrm{Ni}>\mathrm{Pb}$ respectively. The THQ and HI values were $<1$. In conclusion, the study suggests that the risk level of heavy metal exposure via consumption of herbal teas is low with no significant health implications to consumers and may not pose a threat to food safety. (C) JASEM
\end{abstract}

https://dx.doi.org/10.4314/jasem.v21i6.33

Key words: Herbal teas, food safety, health risk assessment, THQ, EDI, HI, toxic metals

Tea is a popular beverage consisting of processed and dried tea leaves (Moghaddam et al., 2008). It is widely consumed around the globe because of its aroma, taste, smell, variety of types and most especially for its multiple promoting health effects (Salahinejad and Aflaki, 2010; Ipeayieda and Dawodu, 2011). Presently in Nigeria there is a growing acceptance of these imported herbal teas among the population as it is believed to have numerous beneficial health effects, such as cancer prevention (Ipeayieda and Dawodu, 2011), diabetes (Vinson and Zhang, 2005; Sajilata et al., 2008) as well as reducing the risk of cardiovascular diseases (Davies et al., 2003). Among the different types of popular teas (Green, Black, Oolong and Puerh teas), green tea is documented to be the most beneficial since it has been proven to contain high amounts of antioxidants which protects against oxidative damages in humans (Kaushik et al., 2011). Herbal teas are highly reputed to restore the body's proper balance and to maintain optimum health by many Nigerians (Orisakwe et al., 2015). Also it has the ability to detoxify the body of alcohol and toxins (Dufresne and Farnworth, 2000).

Contamination of food by heavy metals is detrimental to health and there are currently strict regulations by developed countries to reduce the concentration of toxic metals in food and beverages with regards to the permissible limits outlined by WHO/JECFA, US EPA, and EFSA (Seenivasan et al., 2008). In Nigeria more than $95 \%$ of teas consumed are imported from
China which is the highest exporter of tea globally with 1,726,023 tons produced in 2011 (FAOSTAT 2014).

The quality of tea depends on several factors which includes the cultivated soil, the degree of contamination and atmospheric conditions (Brezichacirocka et al., 2016). It has been reported that the different procedure of processing tea leaves which includes biological and industrial methods does not remove heavy metals, rather they become more concentrated and in turn enter the food chain and ultimately pose serious human health risk to consumers (Ansari et al., 2007; Weldegebriel et al., 2012; Rezaee et al., 2014). However, the evaluation of essential and toxic metals in teas is of great importance considering the potential health risk to habitual tea drinkers if these metals are not within the safe limits (Szymczycha-madeja et al., 2012). Since food ingestion is a major route of exposure to toxic substances (Zhu et al., 2011; Liu et al., 2013), prolonged consumption of toxic metals $(\mathrm{Pb}, \mathrm{Cd}, \mathrm{Cr}$ and $\mathrm{Hg}$ ) which have been reported in teas (Wang et al., 2008; Mania et al., 2014; Li et al., 2015; Orisakwe et al., 2015) might lead to toxic outcomes as a result of bio-accumulation over a life time (Zhou et al., 2016). Also, the presence of essential metals in teas can also exceed the limit associated with their toxicities due to regular consumption.

Herbal teas sold in Nigeria are consumed indiscriminately for therapeutic purposes among the population, therefore there is the need to monitor the 
levels of heavy metals in imported herbal teas with respect to their permissible limits. This study is aimed at investigating the concentration of toxic $(\mathrm{Pb}$, $\mathrm{Ni}$ and $\mathrm{Cr}$ ) and essential $(\mathrm{Zn}, \mathrm{Fe}$ and $\mathrm{Cu}$ ) metals present in various brands of herbal teas, calculate the Estimated Daily Intake (EDI) of metals, Target hazard quotient (THQ), Hazard Index (HI) and also the cancer risk associated with consumption of herbal teas available in the market in southern Nigeria.

\section{MATERIALS AND METHODS}

Collection of samples: A total of 28 samples of imported herbal tea bags sold in major supermarkets were bought from three different cities in Southern Nigeria namely Port-Harcourt, Yenagoa and Owerri in September 2015.

Sample Preparation: The glass beakers and containers used for analysis were washed with detergents and rinsed with double distilled water. $0.5 \mathrm{~g}$ of each herbal tea sample was weighed accurately, ground and transferred into a glass beaker. $\mathrm{HNO}_{3}$ and $\mathrm{HClO}_{4}$ were added in a ratio of 5:1. The samples were kept standing overnight at room temperature for pre-digestion. The mixture was heated on a hot plate $\left(130^{\circ} \mathrm{C}, 30 \mathrm{mins}-1 \mathrm{hr}\right)$ until the solution became transparent and semi-dried. It was allowed to cool, afterwards and then transferred to a $50 \mathrm{ml}$ volumetric flask by adding deionized distilled water (Du et al., 2003; Hseu, 2004). Blanks were also prepared using the same procedure.

Quality Assurance; Analysis of Sample; The concentrations of copper $(\lambda=324.7 \mathrm{~nm})$, Lead $(\lambda=$ $283.3 \mathrm{~nm})$, Iron $(\lambda=248.3 \mathrm{~nm})$, Zinc $(\lambda=213.9 \mathrm{~nm})$, Chromium $(\chi=357.9 \mathrm{~nm})$ and Nickel $(\chi=232.0 \mathrm{~nm})$ were determined using solar thermo flame atomic absorption spectrometer model S4 71096 with percentage recovery between 92\%-100\%. The digestion of all tea samples was triplicated and only the mean was reported afterwards.

Health Risk Assessment of Heavy Metals: The following equations were used to calculate the exposure assessment to heavy metals from consumption of herbal teas.

Estimate Daily Intake (EDI): To calculate the estimated daily intake of heavy metals $(\mathrm{mg} / \mathrm{kg} /$ day $\mathrm{Bw}$ ) via consumption of herbal teas we used the equation below;

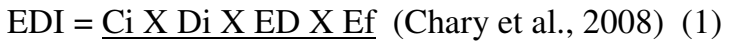

Bw X ATn

Where:

$\mathrm{Ci}=$ Concentration of metals
$\mathrm{Di}=$ Amount of daily intake $(8 \mathrm{~g} /$ person/day Cao et al., 2010; Shen Chen et al., 2008)

$\mathrm{ED}=$ Human lifetime exposure (50 years)

$\mathrm{Ef}=$ Exposure Frequency (350 days/year)

$\mathrm{Bw}=$ Mean body weight $(70 \mathrm{~kg}$ was adopted for Nigerian Adults)

ATn $=$ Average Time for non-carcinogen $(17,500)$

$\mathrm{Sf}=$ Slope factor of the metal $(\mathrm{mg} / \mathrm{kg} /$ day $)$

Reference dose $=\mathrm{Fe}(0.7), \mathrm{Zn}(0.3), \mathrm{Cu}(0.04), \mathrm{Pb}$ (0.004), Ni (0.02), Cr (1.5). (US EPA 2015)

Target Hazard Quotient (THQ): To calculate for Non-carcinogenic risk of heavy metals exposure. The hazard quotient of a single contaminant is determined by the equation below:

Target Hazard Quotient $=$ Exposure dose $($ Wang et al., 1998)

Reference dose

Hazard Index: To calculate the total risk for a combination of heavy metals, the hazard index of the heavy metals is calculated from the equation below; Hazard Index $=\Sigma$ THQ $\quad($ US EPA 1986)

\section{RESULTS AND DISCUSSION}

Levels of Heavy Metals in Herbal Teas: The concentration of heavy metals $(\mathrm{Cu}, \mathrm{Zn}, \mathrm{Fe}, \mathrm{Pb}, \mathrm{Cr}$, and $\mathrm{Ni}$ ) in imported herbal tea samples sold and commonly consumed in southern Nigeria are presented in Table 1. The maximum levels of copper observed in herbal tea samples were seen in liver cleanser, MWT, LGT, TFR and BOD samples with average concentrations of $6.59 \mathrm{mg} / \mathrm{kg}$ while the least levels were seen in SLT and Rheumatic and Arthritis tea samples with a mean concentration of 2.66 $\mathrm{mg} / \mathrm{kg}$. Essential metals required by humans have also been documented to accumulate in tea despite the many reports about toxic heavy metals (Rezaee et al., 2011). In recent years researchers have demonstrated that regular consumption of tea can significantly contribute to the daily dietary intake of essential elements (Karak and Bhagat, 2010; Malik et al., 2013; Li et al., 2016). Although tea is described as the most consumed beverage after water, as well as a rich source of some essential dietary metals (Tea Council, 2004).The highest concentration of $\mathrm{Fe}$ was observed to be in Liver cleanser, ETM and LGT with 453,318 and $317 \mathrm{mg} / \mathrm{kg}$ respectively, the least levels were 141.3 and $141 \mathrm{mg} / \mathrm{kg}$ as detected in TTG and ADT respectively. Heavy metal concentration varied among the different brands of herbal teas in the present study. This may be attributed to diverse sources of these herbal teas which are marketed in Nigeria under different labels laying claim to 
multiple therapeutic potentials. Fernandez-Carcecres et al., in 2001 confirmed in their study that concentration of metals in tea varieties can be an adequate parameter to differentiate teas and their geographical origins. This statement is in agreement with the large variation of heavy metal concentrations in our study. Trade liberalization in Nigeria has led to the flooding of the Nigerian market with sundry items of which herbal teas is not an exception (Orisakwe et al., 2015). Therefore there is the need to constantly monitor the level of contaminants in imported products especially food products.

On the other hand, MWT, BOD and Anti-Cancer had the highest concentration of Zinc ( $\mathrm{Zn}$ ) with levels of $126.1,54.7$ and $57.2 \mathrm{mg} / \mathrm{kg}$ respectively while levels of $22.5,23.3$ and $24.9 \mathrm{mg} / \mathrm{kg}$ detected in STE, SLT and TTG respectively were the least. Furthermore, the concentration of Chromium (Cr) was highest in Liver cleanser and UOG teas which recorded concentration levels of 9.16 and $9.64 \mathrm{mg} / \mathrm{kg}$ while the least levels were observed in MNHT and CCT teas with concentrations of 0.39 and $1.38 \mathrm{mg} / \mathrm{kg}$. Lead levels in herbal teas were found to be highest in neck and spinal cord, BFR, TFR and MNHT teas with concentrations ranging from $0.52-0.8 \mathrm{mg} / \mathrm{kg}$ while the minimum concentrations ranged from $0.04-0.07$ $\mathrm{mg} / \mathrm{kg}$ in after stroke recovery, Rheumatic and Arthritis and STE teas respectively. Nickel (Ni) concentrations were highest in SBT, LYL and MNHT with levels ranging between 5.14 and 5.85 $\mathrm{mg} / \mathrm{kg}$ with least levels found in ADR, ETM, CCT and UOG teas with a concentration of $0.01 \mathrm{mg} / \mathrm{kg}$.

Over the years, researchers have documented in literature that tea consumption is a potential source of toxic metal exposure (Salahinejad and Aflaki, 2010; Schwalfenberg et al., 2013 and Li et al., 2015). Also, tea plants show strong evidence in its ability to take up non-essential metals (Karak and Bhagat, 2010) from the soil and inevitably move to the tea leaves (Jin et al., 2005) which is the primary raw materials used in the production of tea. The individual concentrations of $\mathrm{Pb}$ in herbal tea samples ranged between $0.005-0.8 \mathrm{mg} / \mathrm{kg}$ in the present study, these values are in accordance with the levels of $\mathrm{Pb}$ found in teas marketed in India (Seenivasan et al., 2008) but lower than the values reported in China ( $\mathrm{Li}$ et al., 2015). Also high levels of $\mathrm{Pb}$ were found in tea samples from Japan ranging between $0.51-1.5 \mathrm{mg} / \mathrm{kg}$
(Brzezicha-Cirocka et al., 2015). The high levels of $\mathrm{Pb}$ in Tea samples could be attributed to dust particles during tea processing and the solder used for packaging (Ashraf and Mian, 2008).

The analyzed herbal tea samples were seen to contain high levels of Nickel, though this toxic metal was detected in $100 \%$ of the analyzed tea samples. The present study showed that the level of $\mathrm{Ni}$ in herbal teas ranged from $0.01-6.72 \mathrm{mg} / \mathrm{kg}$, this values are in contrast and found to be lower than those reported by Marcos et al., 1998 with range between 2.99-22.6 $\mathrm{mg} / \mathrm{kg}$ also herbal teas from Thailand with concentration ranging from $2.281-9.19 \mathrm{mg} / \mathrm{kg}$ (Nookabkaew et al., 2006). In another study, tea samples from Turkey contained $\mathrm{Ni}$ concentrations ranging between $10.8-38.8 \mathrm{mg} / \mathrm{kg}$ (Narin et al., 2004).

Various studies have reported the health implications of $\mathrm{Cr}$ as a major food contaminant (Cao et al., 2010; Guerra et al., 2012) because of its well-known toxic potential. $\mathrm{Cr}$ is usually available in two forms, $\mathrm{Cr}^{3+}$ and $\mathrm{Cr}^{6+}$. In our present study the determination of $\mathrm{Cr}$ was not specie specific so we assume $\mathrm{Cr}^{3+}$ since $\mathrm{Cr}^{6+}$ could be reduced to $\mathrm{Cr}^{3+}$ in the stomach under acidic pH (De flora et al., 1997). The concentration of $\mathrm{Cr}$ in our study ranged from $0.39-7.61 \mathrm{mg} / \mathrm{kg}$ which is relatively higher than the values reported for teas from China, India and Japan (Brzezicha-cirocka, 2016). A study by Ferrara et al., 2001 reported $\mathrm{Cr}$ concentrations in Chinese teas to be between 17.9$115.4 \mathrm{mg} / \mathrm{kg}$. These values are higher than the result of our study. Though few studies have assessed the content of $\mathrm{Cr}$ in teas, the varying concentrations from different studies which were neither consistent nor corresponded with our study could probably be as a result of geographical origin or the different processing procedures involved in tea production (Seenivasan et al., 2008).

Therefore the incessant consumption of these herbal teas by Nigerians in search of health benefits could reach limits that are linked to its toxicity. The content of $\mathrm{Cu}$ in the study ranged from $2.49-6.72 \mathrm{mg} / \mathrm{kg}$ with an average content of $4.54 \mathrm{mg} / \mathrm{kg}$ which is low when compared with the result of Qin and Chen 2007 $(17.13 \mathrm{mg} / \mathrm{kg})$, Jin et al., $2008(13.26 \mathrm{mg} / \mathrm{kg})$ and $\mathrm{Li}$ et al., $2015(18.42 \mathrm{mg} / \mathrm{kg})$. 
Table 1: Concentrations $(\mathrm{mg} / \mathrm{kg})$ of heavy metals from Herbal tea samples marketed in Southern Nigeria

\begin{tabular}{|c|c|c|c|c|c|c|}
\hline TEA SAMPLES & $\mathrm{Cu}$ & $\mathrm{Fe}$ & $\mathrm{Zn}$ & $\mathrm{Cr}$ & $\mathrm{Pb}$ & $\mathrm{Ni}$ \\
\hline \multicolumn{7}{|l|}{ Black tea } \\
\hline $\operatorname{Ttg}$ & 5.12 & 141.30 & 24.90 & 4.08 & 0.17 & 4.08 \\
\hline Sbt & 3.68 & 183.20 & 36.20 & 2.69 & 0.34 & 5.14 \\
\hline Lyl & 4.27 & 171.60 & 32.10 & 5.07 & 0.2 & 5.14 \\
\hline \multicolumn{7}{|l|}{ Anti-diabetic tea } \\
\hline Adr & 4.15 & 134.60 & 29.20 & 3.99 & 0.27 & 0.01 \\
\hline Adt & 3.97 & 141.00 & 27.80 & 2.77 & 0.42 & 2.16 \\
\hline \multicolumn{7}{|l|}{ Sexual enhancement tea } \\
\hline Mnht & 3.69 & 245.40 & 33.30 & 0.39 & 0.52 & 5.85 \\
\hline Etm & 5.16 & 318.90 & 34.10 & 6.68 & 0.21 & 0.01 \\
\hline Mwt & 6.68 & 204.10 & 126.10 & 2.35 & 0.31 & 0.85 \\
\hline \multicolumn{7}{|c|}{ Anti-hypertensive \& cholesterol } \\
\hline Cct & 3.84 & 261.20 & 32.90 & 1.38 & 0.22 & 0.01 \\
\hline $\mathrm{Ctt}$ & 4.11 & 175.10 & 36.10 & 3.12 & 0.2 & 2.2 \\
\hline Hes & 3.89 & 163.30 & 29.60 & 4.13 & 0.27 & 4.19 \\
\hline \multicolumn{7}{|l|}{ Fat reducing } \\
\hline Bfr & 3.88 & 161.30 & 29.90 & 3.82 & 0.54 & 1.84 \\
\hline Tfr & 6.56 & 211.10 & 71.90 & 5.98 & 0.8 & 3.49 \\
\hline \multicolumn{7}{|l|}{ Green tea } \\
\hline Qgt & 4.13 & 152.70 & 32.40 & 5.49 & 0.26 & 1.49 \\
\hline Lgt & 6.64 & 317.10 & 31.80 & 7.61 & 0.33 & 1.69 \\
\hline \multicolumn{7}{|l|}{ Organic green tea } \\
\hline Uog & 5.96 & 161.80 & 32.80 & 9.64 & 0.39 & 0.01 \\
\hline Bod & 6.34 & 202.20 & 54.70 & 5.12 & 0.31 & 4.98 \\
\hline \multicolumn{7}{|l|}{ Sleeping tea } \\
\hline Slt & 2.94 & 154.10 & 23.30 & 2.6 & 0.41 & 4.33 \\
\hline Ste & 3.16 & 192.70 & 22.50 & 5.1 & 0.05 & 0.34 \\
\hline Others & 3.13 & 293.30 & 57.20 & 6.61 & 0.14 & 6.72 \\
\hline $\begin{array}{l}\text { Anti-cancer tea } \\
\text { Ginseng tea }\end{array}$ & 4.08 & 187.90 & 31.20 & 2.58 & 0.33 & 4.54 \\
\hline Stop smoking tea & 5.16 & 280.80 & 31.40 & 5.07 & 0.41 & 0.86 \\
\hline Neck \& spinal cord tea & 4.24 & 187.30 & 43.10 & 3.98 & 0.64 & 0.75 \\
\hline After stroke recovery tea & 3.26 & 279.70 & 35.10 & 6.64 & 0.04 & 1.53 \\
\hline Rheumatic \& arthritis & 2.97 & 190.90 & 37.70 & 4.17 & 0.07 & 3.6 \\
\hline Digestive system & 5.54 & 236.10 & 24.50 & 4.18 & 0.22 & 0.86 \\
\hline Liver cleanser & 6.72 & 453.10 & 28.80 & 9.16 & 0.47 & 3.58 \\
\hline Anti-malaria & 3.89 & 169.10 & 39.50 & 2.66 & 0.29 & 1.69 \\
\hline
\end{tabular}

With respect to Fe, Mihaljev et al., 2014 reported a range of $61.87-673 \mathrm{mg} / \mathrm{kg}$ among herbal teas in Serbia. Similarly, Fe content ranging between 141$453 \mathrm{mg} / \mathrm{kg}$ observed in our study can be compared with the result of Salahineijad and Aflaki, 2009 who reported a mean concentration of $169.19 \mathrm{mg} / \mathrm{kg}$ in teas consumed in Iran. According to the report of Ghoochani et al., 2015,
Zn levels among black teas cultivated in Iran had a concentration ranging from $17.43-113 \mathrm{mg} / \mathrm{kg}$. On the other hand, Mmoghaddam et al., 2007 reported an average $\mathrm{Zn}$ content of $50.7 \mathrm{Mg} / \mathrm{kg}$ in Iranian consumed tea which can be compared with the result of our study with an average concentration of 38.2 $\mathrm{mg} / \mathrm{kg}$ in herbal tea samples 
Table 2: Estimated Daily Intake (EDI) of heavy metals $\left(\mathrm{mg} / \mathrm{kg}\right.$ day $\left.{ }^{-1} \mathrm{Bw}^{-1}\right)$ from consumption of Herbal Teas marketed in Southern Nigeria

\begin{tabular}{|c|c|c|c|c|c|c|}
\hline TEA SAMPLES & $\mathrm{Cu} \mathrm{X} 10^{-4}$ & $\mathrm{Fe} X 10^{-2}$ & $\mathrm{ZnX} 10^{-3}$ & $\mathrm{Cr} \times 10^{-4}$ & $\mathrm{~Pb} \times 10^{-5}$ & $\mathrm{Ni} \times 10^{-4}$ \\
\hline \multicolumn{7}{|l|}{ BLACK TEA } \\
\hline TTG & 5.63 & 1.55 & 2.74 & 4.49 & 1.87 & 4.49 \\
\hline SBT & 4.05 & 2.02 & 3.98 & 2.96 & 3.74 & 5.65 \\
\hline \multicolumn{7}{|l|}{ ANTI DIABETIC TEA } \\
\hline ADR & 4.57 & 1.52 & 3.21 & 4.39 & 2.97 & 0.01 \\
\hline ADT & 4.37 & 1.55 & 3.06 & 3.05 & 4.62 & 2.38 \\
\hline \multicolumn{7}{|l|}{ SEXUAL ENHANCEMENT TEA } \\
\hline MNHT & 4.06 & 2.69 & 3.66 & 0.43 & 5.72 & 6.44 \\
\hline ETM & 5.68 & 3.51 & 3.75 & 7.35 & 2.31 & 0.011 \\
\hline MWT & 7.35 & 2.25 & 13.87 & 2.59 & 3.41 & 0.94 \\
\hline \multirow{2}{*}{\multicolumn{7}{|c|}{$\begin{array}{l}\text { ANTI HYPERTENSIVE \& } \\
\text { CHOLESTEROL }\end{array}$}} \\
\hline & & & & & & \\
\hline $\mathrm{CCT}$ & 4.22 & 2.87 & 3.62 & 1.52 & 2.42 & 0.011 \\
\hline CTT & 4.52 & 1.93 & 3.97 & 3.43 & 2.2 & 2.42 \\
\hline $\mathrm{HCS}$ & 4.28 & 1.79 & 3.26 & 4.54 & 2.97 & 4.61 \\
\hline \multicolumn{7}{|l|}{ FAT REDUCING } \\
\hline BFR & 4.27 & 1.77 & 3.29 & 4.2 & 5.94 & 2.02 \\
\hline TFR & 7.22 & 2.32 & 7.91 & 6.58 & 8.80 & 3.84 \\
\hline \multicolumn{7}{|l|}{ GREEN TEA } \\
\hline QGT & 4.54 & 1.68 & 3.56 & 6.04 & 2.86 & 1.64 \\
\hline LGT & 7.30 & 3.48 & 3.49 & 8.37 & 3.63 & 1.86 \\
\hline \multicolumn{7}{|l|}{ ORGANIC GREEN TEA } \\
\hline UOG & 6.56 & 1.78 & 3.61 & 10.6 & 4.29 & 0.011 \\
\hline BOD & 6.97 & 2.22 & 6.02 & 5.63 & 3.41 & 5.48 \\
\hline \multicolumn{7}{|l|}{ SLEEPING TEA } \\
\hline SLT & 3.23 & 1.69 & 2.56 & 2.86 & 4.51 & 4.76 \\
\hline STE & 3.48 & 2.12 & 2.48 & 5.61 & 5.50 & 0.37 \\
\hline OTHERS & 3.44 & 3.23 & 6.29 & 7.27 & 1.54 & 7.39 \\
\hline \multicolumn{7}{|l|}{ ANTI CANCER TEA } \\
\hline GINSENG TEA & 4.48 & 2.07 & 3.43 & 2.84 & 3.63 & 4.99 \\
\hline STOP SMOKING TEA & 5.68 & 3.09 & 3.45 & 5.58 & 4.51 & 0.95 \\
\hline NECK \& SPINAL CORD TEA & 4.66 & 2.06 & 4.74 & 4.38 & 7.04 & 0.83 \\
\hline AFTER STROKE RECOVERY & 3.59 & 3.08 & 3.86 & 7.30 & 4.40 & 1.68 \\
\hline \multicolumn{7}{|l|}{ TEA } \\
\hline RHEUMATIC \& ARTHRITIS & 3.27 & 2.09 & 4.15 & 4.59 & 7.70 & 3.96 \\
\hline DIGESTIVE SYSTEM & 6.09 & 2.59 & 2.69 & 4.6 & 2.42 & 0.95 \\
\hline LIVER CLEANSER & 7.39 & 4.98 & 3.17 & 10.08 & 5.17 & 3.94 \\
\hline ANTI MALARIA & 4.28 & 1.86 & 4.35 & 2.93 & 3.19 & 1.86 \\
\hline
\end{tabular}

Health Risk Assessment: The calculated estimated daily intake (EDI) of essential and toxic metals for individual herbal teas is presented in Table 2. The EDI of heavy metals via consumption of herbal teas showed that $\mathrm{Fe}$ contributed the most to the daily intake of metals while $\mathrm{Pb}$ contributed the least. The mean average of EDI of heavy metals were 0.657 , $0.118,0.014,0.014,0.008$ and $0.0009 \mathrm{mg} / \mathrm{kg} / \mathrm{day} \mathrm{Bw}$ in the order of $\mathrm{Fe}>\mathrm{Zn}>\mathrm{Cu}>\mathrm{Cr}>\mathrm{Ni}>\mathrm{Pb}$ respectively. The calculated EDI when compared with the Rfd of the studied heavy metals were all within the Provisional Tolerable Daily Intake (PTDI).

The THQ values of individual metals in herbal teas were all below 1 as outlined in Table 3 while on the other hand the effect via consumption of multiple metals in herbal teas expressed by the total hazard index $(\mathrm{HI})$ value of all investigated metals were all below 1 as shown in Table 3 .

The science of risk assessment provides researchers with severe tools in order to perform computational risk of hazards associated with foods. Although many recent studies only reported the levels/concentrations in teas, this study however, assessed the potential risk of heavy metal exposure via consumption of herbal teas by calculating the EDI of both toxic and essential metals, the THQ and HI proposed by the US EPA to assess the possible non-carcinogenic effects of heavy metals on human (Fu et al., 2015). The calculated EDI via consumption of herbal teas as shown in Table 2 was compared with the concentration of oral exposure to heavy metals that is likely to be without an appreciable risk of deleterious effects over a 
lifetime (IRIS 2011). There are relatively no background data and standards currently available in Nigeria for the assessment of human health risk associated with exposure to heavy metals, so we compared the EDI with the reference doses. The dietary intake of heavy metals arising from consumption of herbal teas tends to be lower than the reference dose in all the samples. The THQ values of individual metals through consumption of herbal teas were all $<1$ as shown in Table 3. Lastly, the combined effects of all the studied heavy metals expressed as $\mathrm{HI}$ were all $<1$, suggesting no significant health implications to the exposed population.

Table 3: Target hazard quotient (THQ) and Hazard index (HI) for Population exposed to Herbal teas in Southern Nigeria.

\begin{tabular}{|c|c|c|c|c|c|c|c|}
\hline TEA SAMPLES & $\mathrm{Cu} \times 10^{-2}$ & $\mathrm{Fe} \times 10^{-2}$ & $\mathrm{ZnX} 10^{-2}$ & $\mathrm{CrX} 10^{-4}$ & $\mathrm{~Pb} \mathrm{X} \mathrm{10^{-3 }}$ & $\mathrm{Ni} \times 10^{-2}$ & Hazard Index \\
\hline \multicolumn{8}{|l|}{ Black tea } \\
\hline $\operatorname{Ttg}$ & 1.41 & 2.22 & 0.91 & 3.00 & 4.70 & 2.24 & 0.05 \\
\hline Sbt & 1.01 & 2.88 & 1.33 & 2.00 & 9.40 & 2.83 & 0.06 \\
\hline Lyl & 1.17 & 2.69 & 1.18 & 4.00 & 5.50 & 2.83 & 0.06 \\
\hline \multicolumn{8}{|l|}{ Anti-diabetic tea } \\
\hline Adr & 1.14 & 2.12 & 1.07 & 3.00 & 7.40 & 0.01 & 0.05 \\
\hline Adt & 1.09 & 2.22 & 1.02 & 2.00 & 11.60 & 1.19 & 0.06 \\
\hline \multicolumn{8}{|l|}{ Sexual enhancement tea } \\
\hline Mnht & 1.02 & 3.86 & 1.22 & 0.30 & 14.30 & 3.22 & 0.08 \\
\hline Etm & 1.42 & 5.01 & 1.25 & 5.00 & 5.80 & 0.01 & 0.08 \\
\hline Mwt & 1.84 & 3.21 & 4.62 & 2.00 & 8.50 & 0.47 & 0.11 \\
\hline \multicolumn{8}{|c|}{ Anti-hypertensive \& cholesterol } \\
\hline Cct & 1.06 & 4.11 & 1.21 & 1.00 & 6.10 & 0.01 & 0.07 \\
\hline $\mathrm{Ctt}$ & 1.13 & 2.75 & 1.32 & 2.00 & 5.50 & 1.21 & 0.06 \\
\hline Hcs & 1.07 & 2.57 & 1.09 & 3.00 & 7.40 & 2.31 & 0.05 \\
\hline \multicolumn{8}{|l|}{ Fat reducing } \\
\hline Bfr & 1.07 & 2.54 & 1.09 & 3.00 & 14.90 & 1.01 & 0.06 \\
\hline Tfr & 1.80 & 3.32 & 2.64 & 5.00 & 22.00 & 1.92 & 0.10 \\
\hline \multicolumn{8}{|l|}{ Green tea } \\
\hline Qgt & 1.14 & 2.39 & 1.19 & 4.00 & 7.20 & 0.82 & 0.05 \\
\hline Lgt & 1.83 & 4.98 & 1.17 & 6.00 & 9.10 & 0.93 & 0.09 \\
\hline \multicolumn{8}{|l|}{ Organic green tea } \\
\hline Uog & 1.64 & 2.54 & 1.20 & 7.00 & 1.07 & 0.01 & 0.07 \\
\hline \multirow{2}{*}{\multicolumn{8}{|c|}{ Sleeping tea }} \\
\hline & & & & & & & \\
\hline Slt & 0.81 & 2.42 & 0.85 & 2.00 & 11.30 & 2.38 & 0.05 \\
\hline $\begin{array}{l}\text { Ste } \\
\text { Others }\end{array}$ & \multicolumn{7}{|c|}{ Others } \\
\hline Anti-cancer tea & 0.86 & 4.61 & 2.09 & 5.00 & 3.90 & 3.69 & 0.08 \\
\hline Ginseng tea & 1.12 & 2.95 & 1.14 & 2.00 & 9.10 & 2.49 & 0.06 \\
\hline Stop smoking tea & 1.42 & 4.41 & 1.15 & 4.00 & 11.30 & 0.47 & 0.08 \\
\hline Neck \& spinal cord tea & 1.17 & 2.94 & 1.58 & 3.00 & 17.60 & 0.41 & 0.07 \\
\hline After stroke recovery tea & 0.89 & 4.39 & 1.29 & 5.00 & 1.10 & 0.84 & 0.07 \\
\hline Rheumatic \& arthritis & 0.82 & 2.99 & 1.38 & 3.00 & 1.90 & 1.98 & 0.05 \\
\hline Digestive system & 1.52 & 3.71 & 0.89 & 3.00 & 6.10 & 0.47 & 0.07 \\
\hline Liver cleanser & 1.85 & 7.12 & 1.06 & 7.00 & 12.90 & 1.97 & 0.11 \\
\hline Anti-malaria & 1.07 & 2.66 & 1.45 & 2.00 & 7.90 & 0.93 & 0.06 \\
\hline
\end{tabular}

Conclusion: Continuous intake of these imported herbal teas is likely going to increase the body burden of toxic metals in habitual tea drinkers. The present study reveals that imported herbal teas are contaminated with toxic metals $(\mathrm{Pb}, \mathrm{Ni}$ and $\mathrm{Cr})$ at concentration higher than the maximum permissible limit. Although the health risk assessment result showed no possible health risk, the fact that the exposed population are exposed to other sources of heavy metal pollution is of public health concern as combined exposure through oral, dermal and inhalation routes could lead to toxic outcomes. Consequently there is the need to enforce strict regulations to monitor the level of heavy metals in imported food products.

\section{REFERENCES}

Aksuner, N; Henden, E; Aker, Z; Engin, E; Satik, S (2012). Determination of essential and non-essential elements in various tea leaves and tea infusions consumed in Turkey. Food Additives and Contaminants: Part B, 5(2), 126-132.

Ansari, F; Norbakhsh, R; Daneshmandirani, K (2007). Determination of heavy metals in Iranian and imported black tea. Environ Health Sci Eng. 4:243-8.

Ashraf, W; Mian, AA (2008). Levels of Selected Heavy Metals in Black Tea Varieties Consumed in Saudi Arabia. Bull Environ Contam Toxicol. 81: 101-104.

Brzezicha-Cirocka, J; Grembecka, M; Szefer, P (2016). Monitoring of essential and heavy metals in green tea 
from different geographical origins. Environ Monit Assess. 188: 183.

Cabrera, C; Gallego, C; Lopez, MC; Lorenzo, ML (1994). Determination of levels of Lead contamination in Food and Feed Crops. Journal of Association of Official methods for Analytical Chemists, 77(5), 12491252.

Cao, H.B; Chen, JJ; Zhang, J; Zhang, H; Qiao, L; Men, Y (2010). Heavy metals in rice and garden vegetables and their potential health risks to inhabitants in the vicinity of an industrial zone in Jiangsu, China. Journal of Environmental Sciences 22: 1792- 1799.

Cao, H; Qiao, L; Zhang, H; Chen, J (2010). Exposure and risk assessment for aluminium and heavy metals in Puerh tea. Science of the Total Environment, 408(14), 2777-2784.

Chary, NS; Kamala, CT; Raj, DSS (2008). Assessing risk of heavy metals from consuming food grown on sewage irrigated soils and food chain transfer. Ecotoxicol. Environ. Safety 69, 513-524.

Chen, RF; Shen, RF; Gu, P; Wang, HY; XU, XH (2008). Investigation of aluminum-tolerant species in acid soils of South China. Communications in Soil Science and Plant Analysis, 39(9-10), 1493-1506.

Davies, MJ; Judd, JT; Baer, DJ; Clevidence, BA; Paul, DR; Edwards, AJ; Wiswman, SA; Muesing, RA; Chen, SC (2003). Black tea consumption reduces total and LDL cholesterol in mildly hypercholesterolemic adults. $J$ Nutr. 133, 3298S-302.

DeFlora, S; Camoirano, A; Bagnasco, M; Bennicelli, C; Corbett, G.E; Kerger, BD (1997). Estimates of the chromium (VI) reducing capacity in human body compartments as a mechanism for attenuating its potential toxicity and carcinogenicity. Carcinogenesis, 18(3), 531-537.

Desideri, D; Meli, MA; Roselli C; Feduzi, L (2011). Polarized X-ray fluorescence spectrometer (EDPXRF) for the determination of essential and non-essential elements in tea. Microchemical Journal, 98, 186-189.

Du Laing, G; Tack, FM; Verloo, M.G (2003). Performance of selected destruction methods for the determination of heavy metals in reed plants (Phragmites australis). Anal Chim Acta 497(1):191-198.

Dufresne, C; Farnworth, E (2000). Tea, Kombucha, and health: a review. Food Res Int 33(6):409-421

Fernandez-Caceres, P; Martin, MJ; Pablos, M; Gonzalez, AG; (2001). Differentiation of tea (Camellia sinensis) varieties and their geographical origin according to their metal content. J Agric Food Chem 49, 47754779

Fu, QL; Li, L; Achal, V; Jiao, AY; Liu, Y (2015). Concentrations of heavy metals and arsenic in market rice grain and their potential health risks to the population of Fuzhou, China. Human and Ecological Risk Assessment: An International Journal, 21(1), 117-128.

Guerra, F; Trevizam, AR; Muraoka, T; Marcante, NC; Canniatti-Brazaca, SG (2012). Heavy metals in vegetables and potential risk for human health. Scientia Agricola 69: 54-60.

Hseu, ZY (2004). Evaluating heavy metal contents in nine composts using four digestion methods. Bioresour Technol 95(1):53-59.

Integrated Risk Information System (IRIS). (2011). U.S EPA hazards and dose response assessments available from https://www.epa.gov/iris. Cited on 29 may 2015.

Ipeaiyeda, AR; Dawodu, M (2011). Leaching of manganese, iron, copper and zinc from tea (Camellia sinensis) in tea mug. Electronic Journal of Environmental, Agricultural and Food Chemistry, 10, 2240-2247.

Jin, CW; Zheng, SJ; He, YF; Zhou, GD; Zhou, ZX (2005). Lead contamination in tea garden soils and factors affecting its bioavailability. Chemosphere. 59(8):1151-9.

Karak, T; Bhagat, RM (2010). Trace elements in tea leaves, made tea and tea infusion: A review. Food Research International 43, 2234-2252.

Kaushik, G; Satya, S; Naik, SN (2011). Green tea: protective action against oxidative damage induced by xenobiotics. Mediterranean Journal of Nutrition and Metabolism. 4(1), 11-31.

Marcos, A; Fischer, A; Gi, L; Fu, Q; Achal, V; Liu, Y (2015). A comparison of the potential health risk of aluminum and heavy metals in tea leaves and tea infusion of commercially available green tea in Jiangxi, China. Environ Monit Assess, 187, 228 DOI 10.1007/s10661-015-4445-2.

Li, Z; Ma, Z; Kuijp, TJ; Yuan, Z; Huang, L (2014). A review of soil heavy metal pollution from mines in China: pollution and health risk assessment. Sci Total Environ 468-469:843-853.

Liu, X; Song, Q; Tang, Y; Li, W; Xu, J; Wu ; Wang, F; Brookes, PC (2013). Human health risk assessment of heavy metals in soil-vegetable system: a multimedium analysis. Science of the Total Environment, $463,530-540$.

Malik, J; Frankova, A; Drabek, O; Szakova, J; Ash C; Kokoska, L (2013). Aluminium and other elements in selected herbal tea plant species and their infusions. Food Chemistry. 139, 728-734

Mania, M; Szynal, T; Rebeniak, M; WojciechowskaMazurek, M; Starska, K; Strzelecka. A; (2014). 
Human exposure assessment to different arsenic species in tea. Rocz Panstw Zakl Hig, 65(4), 281-286.

Marcos, A; Fisher, A; Rea, G; Hill, S.J; (1998). Preliminary study using trace element concentrations and a chemometrics approach to determine geographical origin of tea. Journal of Analytical Atomic Spectrometry, 13, 521-525.

Moghaddam, MA; Mahvi, AH; Asgari, AR; Yonesian, M; Jahed, GH; Nazmara, SH (2008). Determination of aluminum and zinc in Iranian consumed tea. Environ. Monit. Assess. 44(1), 22-30

Narin, I; Colak, H; Turkoglu, O; Soylak, M; Dogan, M (2004). Heavy metals in black tea samples produced in Turkey. Bulletin of Environmental Contamination and Toxicology, 72, 844-849.

Nookabkaew, S; Rangkadilok, N; Satayavivad, J (2006). Determination of trace elements in herbal tea products and their infusions consumed in Thailand. Journal of Agricultural and Food Chemistry, 54, 6939-6944.

Orisakwe, OE; Mbagwu, HOC; Ukpai, P; Udowelle, NA (2015). Survey of polycyclic aromatic hydrocarbons and lead in Chinese teas sold in Nigeria: levels and health implications. Rocz panstw zakl hig, 66 (3):225232.

Patrick, DR (1994). Risk assessment and risk management, in: D.R. Patrick (Ed.), Toxic Air Pollution Handbook, Van Nostrand Reinhold, New York. p. 347.

Rezaee, E; Mirlohi, M; Fallah, A; Babashahi, M (2014). A Systematic Review on Exposure to Toxic and Essential Elements through Black Tea Consumption in Iran: Could It be a Major Risk for Human Health? Int J Prev Med. 5(11), 1351-1359.

Sajilata, MG; Bajaj, PR; Singhal RS (2008). Tea polyphenols as nutraceuticals. Compr Rev Food Sci Food Saf. 7, 229-54.

Salahinejad, M; Flaki, F (2010). Toxic and essential mineral elements content of black tea leaves and their tea infusions consumed in Iran. Biological Trace Element $t$ Eminent Research, 134, 109-117.

Schwalfenberg, G; Stephen, J; Genuis, IR (2013). The Benefits and Risks of Consuming Brewed Tea: Beware of Toxic Element Contamination. Journal of Toxicology.

Seenivasan, S; Manikandan, N; Muraleedharan, NN (2008). Chromium contamination in black tea and its transfer into tea brew. Food Chem. 106, 1066-9.
Seenivasan, SN; Manikandan, NN; Muraleedharan R. Selvasundaram (2008). Heavy metal content of black teas from south India. Food Control. 19, 746-749

Szymczycha-Madeja, A; Welna M; Pohl. P (2012). Elemental analysis of teas and their infusions by spectrometric methods. Trends in Analytical Chemistry. 35,

The Tea Council (2004). Available from http://www.teacouncil. co.uk.

USEPA. 1999. Guidelines for Carcinogen Risk Assessment, NCEA-F-0644, Review Draft, Risk Assessment Forum, Washington, DC.

US EPA. (2015). Regional Screening Level (RSL) Summary Table (TR=1E-6, HQ=1)-January 2015. www.epa.gov/ reg3hwmd/risk/human/rbconcentration_table/Generic_

Tables/docs/master_sl_table_run_JAN2015.pdf. Accessed 22 May 2016.

Vinson, JA; Zhang, J (2005). Black and green teas equally inhibit diabetic cataracts in a streptozotocin-induced rat model of diabetes. J. Agric Food Chem. 53, 37103.

Wang, XP; Ma, YJ; Xu, YC (2008). "Studies on contents of arsenic, selenium, mercury and bismuth in tea samples collected from different regions by atomic fluorescence spectrometry,"

Weldegebriel, Y; Chandravanshi, BS; Wondimu, T (2012). Concentration levels of metals in vegetables grown in soils irrigated with river water in Addis Abada, Ethiopia. Ecotoxicology and Environmental Safety, 77, 57-63.

Wong, MH; Zhang, ZQ; Wong, JW; Lan, CY (1998). Trace metal contents (Al, $\mathrm{Cu}$ and $\mathrm{Zn}$ ) of tea: Tea and soil from two tea plantations, and tea products from different provinces of china. Environ Geochem Health. 20:87

Zhou, H; Yang, WT; Zhou, XL; Liu, JF; Gu, WL; Wang, JL; Zou, T; Tian, PQ; Peng, Liao, BH; (2016). Accumulation of Heavy Metals in Vegetable Species Planted in Contaminated Soils and the Health Risk Assessment. Int. J. Environ. Res. Public Health, 13, 289.

Zhu, F; Fan, W; Wang, X; Qu, L; Yao, S (2011) Health risk assessment of eight heavy metals in nine varieties of edible vegetable oils consumed in China. Food Chem. Toxicol. 49, 3081-3085. 